\title{
Opportunities of Using Space Technology to Enhance Border Security in South Africa
}

\begin{abstract}
Moses Thabo Katjisa Nkhoma ${ }^{a}$, Albert Tchey Agbenyegah ${ }^{b}$, ${ }^{a}$ Department of Business Administration, Faculty of Management Sciences, Durban University of Technology, South Africa. b Durban University of Technology, Riverside Campus, Pietermaritzburg, South Africa, Faculty of Management Sciences, Department of Applied Management. Email: a'mnkhoma@hotmail.co.za, balberta@dut.ac.za
\end{abstract}

The failure of the South African border security authorities to provide effective border security continues to be a national security concern. The inability to provide effective border security is due to factors such as ineffective methods of controlling and monitoring the borders. The aim of this study was to examine the practicability of employing space technology to address identified border security constraints. The study focused on border security authorities and the space technology sector in South Africa. To achieve this objective, a qualitative research methodology was used to ascertain the issues and constraints of border security in South Africa as well as the possibilities of utilising space technology to address border security constraints in South Africa. Findings indicate that there is a need to utilise space technology in South Africa to enhance the level of border security.

Key words: transnational crimes, border security; space technology, unmanned aerial vehicle, satellites

\section{Introduction}

Technology continues to play a critical role in the delivery of various services in many industries and sectors. This includes the defence, safety, and security sectors, where nations make massive investments in emerging technologies to enhance their security, defence, and military capabilities. South Africa faces a significant challenge of providing effective land border security due to several factors. These factors consist of the lack of effective technological solutions to aid border guards in the execution of their mandate; the vastness of the South African land borders; physical and human resource constraints; and the use of 
ineffective border security management measures (TimesLIVE, 2019a; Maqhina, 2019; SA News, 2019; DefenceWeb, 2020).

Given the emerging threats and risks of various cross-border crimes, effective land border security becomes an important component of the entire South African safety and security architecture. Although countries such as the United States of America (USA), India, Egypt, and Europe embrace the use of various technological solutions and innovations, such as satellites and Unmanned Aerial Vehicles (UAVs) for safeguarding, controlling and monitoring their land borders, South Africa is yet to fully adopt these technologies to address its land border security constraints (Thompson, 2013; Gadda \& Patil, 2013; Shishkov, Hristozov \& Janssen, 2017; Van den Hoven, Katara \& Pokhriyal, 2017). In view of the importance of effective border security, this study seeks to give practical solutions for enhancing border security in South Africa through the utilisation of space-based technology.

\section{Statement of the problem}

One of the constraints faced by the South African border security fraternity is the scarce usage of effective technological solutions for border control and monitoring. This may be caused by the lack of appreciation of the value which emerging technologies can add to the effectiveness and efficiency of border security operations. The lack of appreciation of technological solutions may be as result of an organisational culture not supportive of technology; the lack of a clearer strategic border security management that embraces technology; policy red tapes; perceptions that technology is expensive; lack of requisite employee skills to adapt to technological changes an probably, senior management's lack of awareness of effective technological solutions. This lack of appreciation has caused South African border security authorities to fall behind many developed countries who continue to embrace and use technology, particularly space-based technologies for their border security management activities.

Given the identified constraints, the passing of South African Border Management Authority (SABMA) Bill into law in 2020, paved the way for the establishment of a single border security entity that would coordinate and take responsibility for every border security management tasks. Though the establishment of the BMA is most likely to address some of the present-day border security constraints including the fragmented border security management architecture, it remains questionable whether it will address the constraints related to the actual provisioning of effective border security. Against this background, it is important to understand the current constraints of border security management in South Africa, and the opportunities of adopting space-based technology to enhance the effectiveness of border security operations in South Africa. 


\section{Study aims and objectives}

This study investigates the current constraints of border security in South Africa. It also investigates the opportunities of adopting a different border security approach by embracing the use of space-based technology to enhance land border security operations in South Africa. Therefore, the objectives of this study are:

- To identify the constraints of controlling and monitoring South Africa's land borders; and

- To explore the opportunities of employing space technologies for enhancing land border security in South Africa.

\section{Border security: issues and constraints in the South African context}

Border security can be described as a set of proactive and protective measures instituted by governments through several border security agencies in order to prevent or detect security threats and risks such as illegal migration; illegal smuggling of persons and illicit goods, narcotics and drugs; smuggling of firearms, ammunition, or vehicles; or threats of terrorism and insurgency. Border security measures consist of internal enforcement of migration laws; controlling cross-border movements of people and goods; and border patrols by border guards (Mahlangu \& Obioha, 2015; Okumu, 2016).

The issue of border security has assumed heightened significance due to an increase in the rate of illegal migration and transnational criminal activities. Globalisation, and advancements in telecommunication, transportation, and other technologies, have all made it easier for people and criminal networks to move across the world with ease. These developments have meant that the control and detection of illegal migration and transnational crimes has become a major focus of border security (Caparini \& Marenin, 2006; Segell, 2005; Lynch \& Hadjimatheou, 2012; Akinyemi, 2013; Okumu, 2016). African countries, South Africa included, are not spared from this phenomenon, and are also overwhelmed by a variety of traditional and nontraditional security threats and risks. This situation has compelled African countries and institutions to rethink and assess the nature of security along the lines of whom and what needs to be secured and protected (Solomon, 2015; Erasmus, 2020).

Many countries find it difficult to detect and intercept intruders and criminal elements who attempt to cross their international borders. These intruders are mainly transnational criminal networks; illegal migrants, human smugglers and traffickers, drug and narcotics smugglers, and other persons who represent a threat to national security and the interests of a country, as is the case with South Africa. One of the primary constraints experienced by the South African border authorities in controlling and monitoring long stretches of a country's borders is the need for intensive human involvement. This situation has prompted border security authorities, 
for example in India, Switzerland, Egypt, and the USA, to seek alternative measures and technological solutions such as the employment of space-based technologies to control and monitor their international borders (Pedrozo, 2016; Kumar, 2019; Alkhathami, Alazzawi \& Elkateeb, 2015; The Economic Times, 2019; Wilson, 2018).

Baker (2009) also asserts that the task of securing South Africa's borders is a daunting one and requires a unique set of capabilities, which is not possessed by either the South African Police Services (SAPS) or the South African National Defence Force (SANDF). The author (2009) asserts that the task requires a set of capabilities that fall somewhere between these two entities. The task requires robust patrolling of vast and difficult terrain, which SAPS is not trained or equipped to execute. On the other hand, the border safeguarding task requires the responsible entity to enforce the law, and detain and process suspected criminals and illegal migrants, which is a task the SANDF is not capable of executing. In support, Molemma (2017) suggest that the return of the SANDF to the borderline has had little impact on combating cross-border criminal activities, such as human trafficking. This is mainly due to limited resources to patrol the land borders and to monitor the coastline and the airspace. The author (2017) suggested that more personnel should be deployed in the areas affected by the illegal movement of persons and goods, and new technology should be employed to monitor the borders.

Crush and Williams (1999) also suggest that South Africa has highly porous borders, which are beneficial to many migrants who want to avoid legal migration channels due to the fear of harassment, discrimination, and deportation. Similarly, Tati (2008) and Dithebe and Mukhuba (2018) state that South Africa's borders with its neighbours are extremely porous and they have often been blamed for the problem of illegal migration and the challenge of stabilising the number of migrants in South Africa. Moreover, border jumping presents itself as the preferred option for many migrants who want to enter the country as South Africa's migration legislation is regarded as complicated when it comes to the facilitation of migration documentation required for legal entry into the country. The ability of the South African border authorities to exercise control over South African borders is of paramount importance for key national priorities such as stability and national security. This will also enable the State to discharge its responsibilities within its territory and further achieve its political, legal, and economic objectives. Thus, the issue of effective border security, which is a critical factor of border management, becomes a key national security priority for consideration for South Africa.

\section{Utilisation of space technology for border security activities}

Several space technologies in the form of video surveillance, radars and satellites are employed by border security entities to control and monitor national territories. Drones form part of these border security technologies and have been identified as a key tool in the surveillance and identification systems (Klauser \& Pedrozo, 2015). Alternatively, border authorities use wireless sensors and ground-based electro-optical sensors, which are linked to satellites to 
monitor and control borders. However, South Africa remains behind in these global developments (Felemban, 2013; Szechtman, Kress, Lin \& Cfir, 2007).

Conventional systems of border security in South Africa typically consist of border guards and border posts along international roads. At these border posts, the traffic is stopped, and both the vehicles and passengers are inspected to detect any illegal activities. In between the border posts, border guards patrol the border area, using existing routes, at predetermined intervals. This task requires the involvement of extensive human resources, even to patrol small border areas. Moreover, foot and vehicle patrols are easy to observe and predict, and intruders will often familiarise themselves with the border guard patrol routine and will capitalise on their periods of absence to cross borders illegally. Although South Africa's borders are manned by the military, the length of the borders which is approximately 4700 kilometres; harsh terrains; extreme weather conditions and the dark of night make it difficult to launch patrols at any time. These conditions provide ample opportunities to intruders to execute their criminal intents (Wang, Sun, Vuran, et al., 2011; Emad, 2013).

The invention of different technologically based patrol techniques, which could help decrease the need for intensive human involvement and vehicles in border patrol activities; have the flexibility to be deployed at any time in any border region; and also have a greater detection capacity have become a necessity (Esterhuyse, 2019). As stated by Wilson (2018), monitoring international borders using human eyes and outdated methods is no longer the only option, although these are a vital part of a complete border security approach. The author suggests that existing border security measures ought to be augmented by technological solutions and innovations. The author added that countries are resorting to space-based technologies to control and monitor their borders. Similar sentiments are held by Alkhathami, Alazzawi and Elkateeb (2015) when the authors state that one of the constraints regarding the protection of large stretches of border area is the need for intensive human involvement for border control and monitoring. Alkhathami, Alazzawi and Elkateeb (2015) further suggest the invention of various technological aids to decrease the need for such intensive human measures. A variety of space-based technologies are available on the market or could be developed and integrated to perform a variety of border monitoring activities. These space-based technologies would include satellite technology; aerostats; UAVs; manned aircrafts; sensor-packed UAVs; and remote sensing technology. These technologies are intended to provide border security authorities with situational awareness; optimise border patrol activities; and enable them to react quickly to cross-border criminal activities, such as illegal migration (Klauser \& Pedrozo, 2015; Wilson, 2018).

Technological innovations and advances in areas such as aerial platforms, image sensors and processing, as well as geo-positioning systems enable near real-time detection and tracking of moving objects on the ground in a more practical and cost-effective manner. These technologies could be ideal for a near real-time monitoring of international border areas, which 
experience frequent and significant acts of illegal immigration and smuggling. They could assist border security authorities to locate and monitor the movement of people and vehicles across international borders. Low-cost aerial platforms, such as light aircraft or UAVs, could provide repeat imaging over a short period. Other automated specialised image collection and processing techniques used in border areas assist in detecting changes associated with security threats along a country's border (Coulter, Lippitt, Stow \& McCreight, 2011).

\section{Methodology}

This study adopts the philosophy of pragmatism and grounded in two orientations of problemsolving and real-world practice. Being a qualitative study, the author utilised documents analysis and semi-structured interviews. Document analysis consisted of the collection and analysis of official statements and reports by senior SANDF members which focus mainly on threats and risks of South African border security. Specifically, the study explores the constraints experienced by the SANDF in borderline control and monitoring. The study also explores alternative border security enhancement measures for South Africa. The author also conducted semi-structured interviews with members of SAPS border policing and subjects' experts in border security and space technology. The empirical data collected during this study was instrumental to the understanding of the phenomenon under study and in providing possible solutions to the identified study problem.

\section{Data collection and analysis}

The author used documentary analysis to gain an in-depth knowledge of the challenges of border security in South Africa and to understand the value which space technology can add in enhancing border security in South Africa. As guided by De Vos, Strydom, Fouche, \& Delport (2005), the author studied and analysed 21 official SANDF documents consisting of official statements and media reports. Other documents analysed in this study were video interview recordings by senior members of the SANDF. These video recordings were sourced from various media houses such as the South African Broadcasting Authority (SABC) and eNCA through YouTube. The author also collected data by applying Key Informant Interviews (KII) whilst using semi-structured interviews. A small number of participants with in-depth knowledge of the topic at hand were interviewed by the author (Kumar, 1989; Given, 2008). Participants in this study consisted of senior police officials responsible for land border security at selected land border areas in South Africa; authors and experts on border security; authors and experts on satellite technology; and authors and experts on UAV technology. Due to practical constraints, and in consideration of the restrictions imposed by the Covid 19 pandemic and the related safety measures, the author used virtual interview methods to collect data from the participants. Thus, the author conducted video interviews, telephonic interviews, and email interviews with the identified participants. 
The author used thematic analysis to analyse data collected in this study (Braun \& Clarke, 2006). To simplify the data analysis process, the audio recordings obtained during the semistructured interviews were transcribed verbatim into notes so that they could be read, edited for accuracy, commented on, and analysed in order to identify common themes (Welman et al., 2005). Following this, the author used a Computer-Aided Qualitative Data Analysis Software (CAQDAS), Atlas ti ${ }^{\mathrm{TM}}$, to code the semi-structured interview transcripts (DeNardo \& Levers, 2002; Corti \& Gregory, 2011). The use of Atlas ti ${ }^{\mathrm{TM}}$ made it easy to analyse textual data and further made it easier to identify key themes as they emerged from the collected data.

\section{Findings}

Figures were employed by the author to present frequencies of subthemes which emerged from participants responses. The frequencies of the subthemes which emerged during the study are presented in percentage format using pie chart.

\section{Constraints of border security in South Africa}

During the documentary analysis process, the author identified selected constraints related to the provision of effective border security in South Africa as depicted in Figure 1 on the following page. These constraints consisted of the absence of a borderline fence (27\%), an unfavourable border terrain and typology (23\%), and the lack of resources (23\%). Other constraints identified by the author include lack of resources and insufficient funding, each with relative frequency of $18 \%$ and insufficient manpower at $14 \%$.

\section{Figure 1: Opinions of SANDF on the constraints of border security in South Africa}

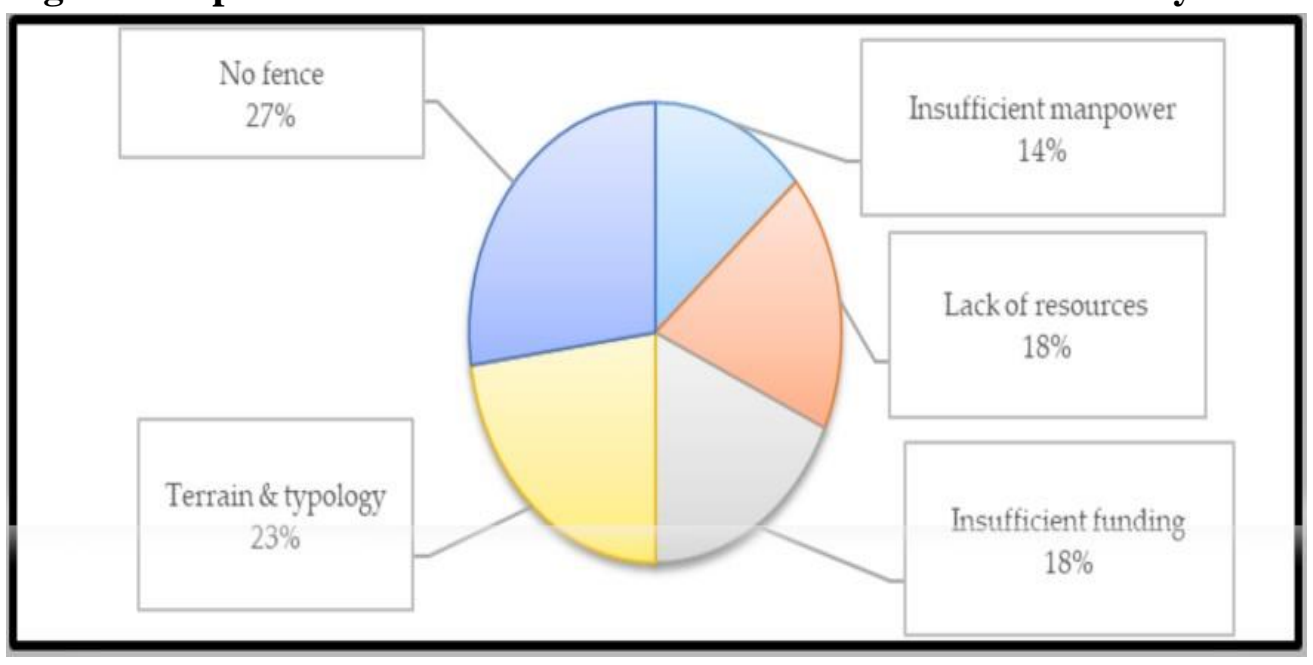

Supporting the documentary analysis process, border policing officials interviewed by the author mentioned several constraints in relation to control and monitoring measures practiced at the borderline. Figure 2 below depicts some of the participants constraints. The border area terrain and typology which made it difficult for border security authorities to patrol (27\%), the 
porous borderline (20\%). Other factors include lack of suitable vehicles to patrol the borderline; inadequate resources to render effective border security; and the lack of a border security strategy each at a frequency of $13 \%$. Corruption and the lack of technology, each at a relative frequency of $7 \%$, were also mentioned by the participants as the constraints of border security at various border areas across South Africa.

Figure 2: Opinions of SAPS officials on the constraints to border security in South Africa

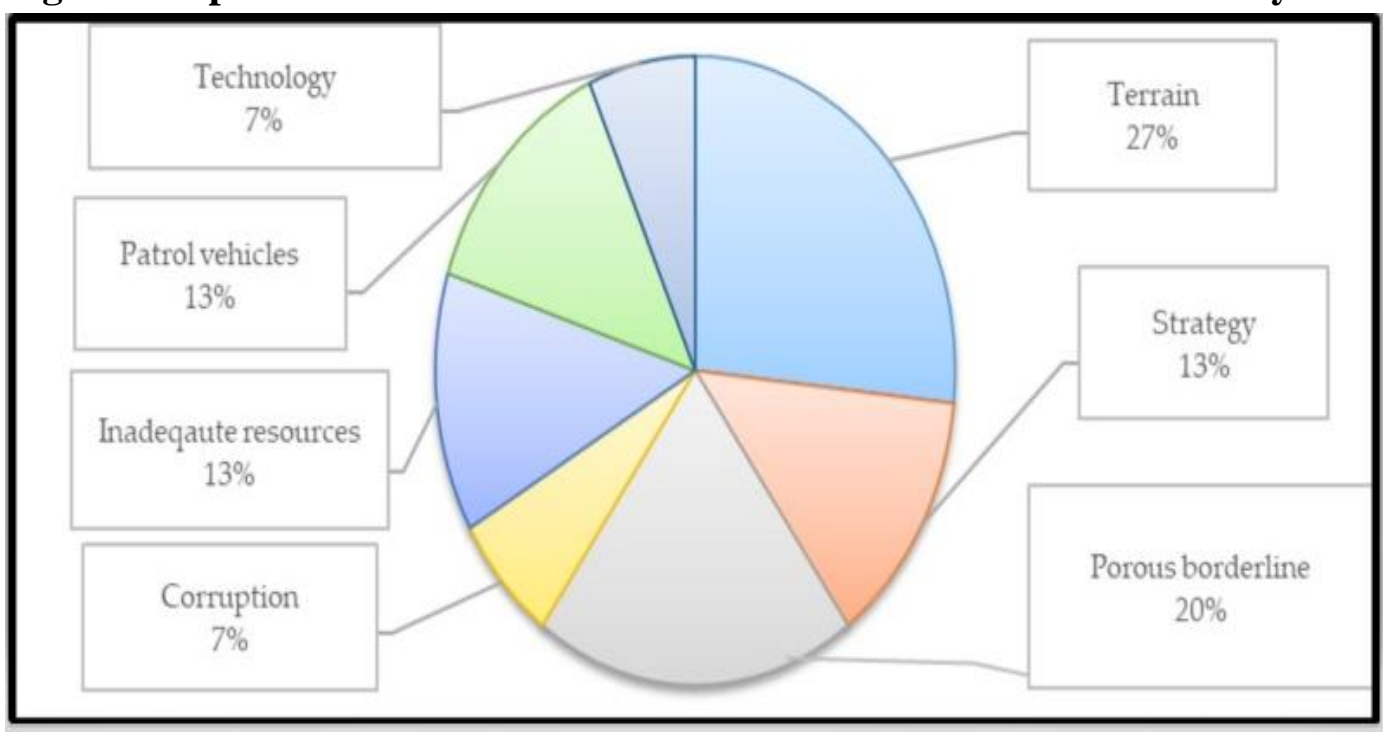

Border security experts as shown in Figure 3 below expressed their views on the nature of constraints faced by border security authorities in South Africa. They mentioned constraints that include capacity constraints (29\%), the porosity of the borderline because of the lack of borderline infrastructure (29\%); and poor border security strategy $(21 \%)$. In addition, the border security experts highlighted the unfavourable border terrain and typology (21\%) which made it difficult to control and monitor the South African borderline as another significant challenge of border security in South Africa. 
Figure 3: Opinions of border security experts on the constraints of border security in South Africa

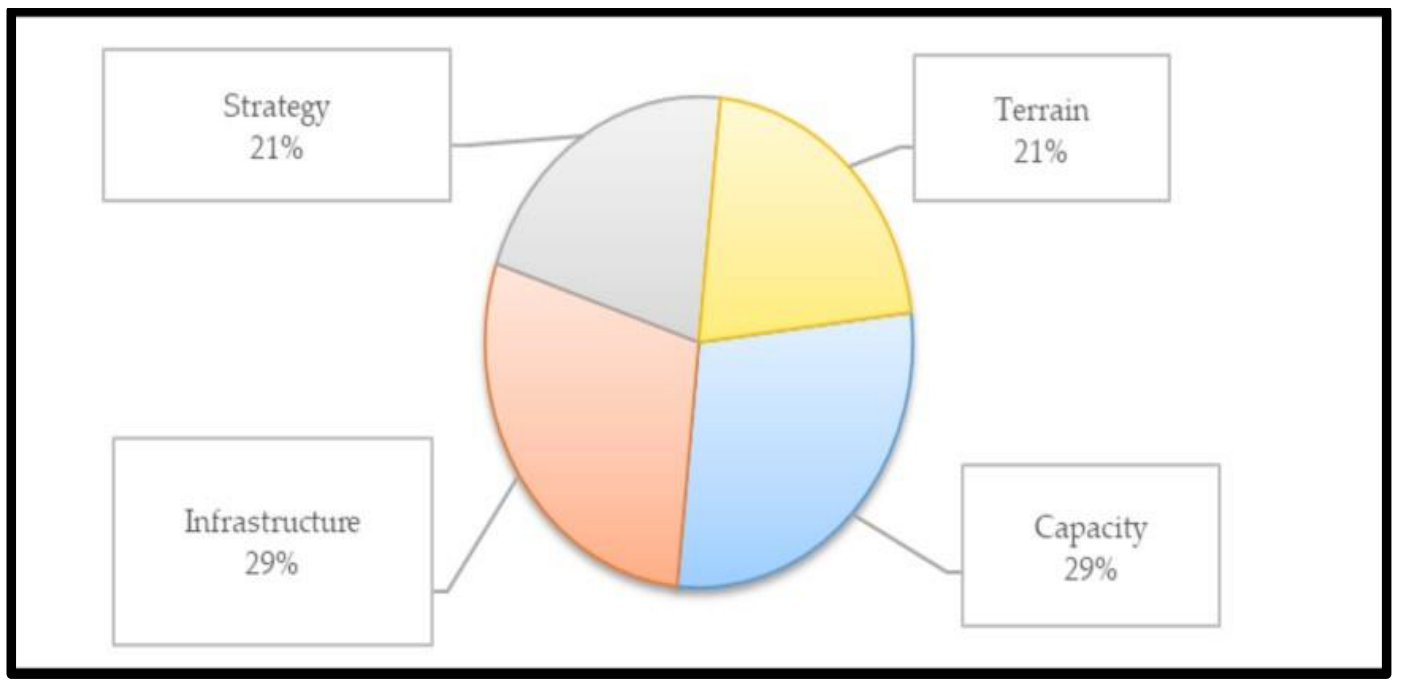

Given the above, the results of the documentary analysis process and semi-structured interviews revealed several critical constraints faced by border security authorities in providing effective border security management in South Africa. These processes revealed that it is often a challenge to control and monitor the South African borders due to the unfavourable border terrain which is difficult to patrol using conventional methods such as foot and vehicle patrols.

Inadequate resources and the underfunding of border security authorities also continue to hamper the ability of these authorities to render effective border security in South Africa. Another critical shortfall of providing effective border security revealed in this study was the lack or absence of an effective border security strategy. The identified constraints in this study highlight the need for innovative thinking to enhance border security management in South Africa. The identified constraints that were highlighted need deeper exploration in terms of technological innovations and solutions to complement existing approaches to border security in South Africa.

Opportunities and possibilities of utilising space technology to enhance South African border security

While exploring the possibility of employing space-based technology to enhance border security in South Africa, documentary analysis as in Figure 4 below illustrates the deployment of hi-tech technology (38\%); the utilisation of UAVs (38\%); and the installation of sensors along the borderline (25\%) can be of value in enhancing border security management activities in South Africa. 
Figure 4: Opinions of the SANDF on the use of technology for border security in South Africa

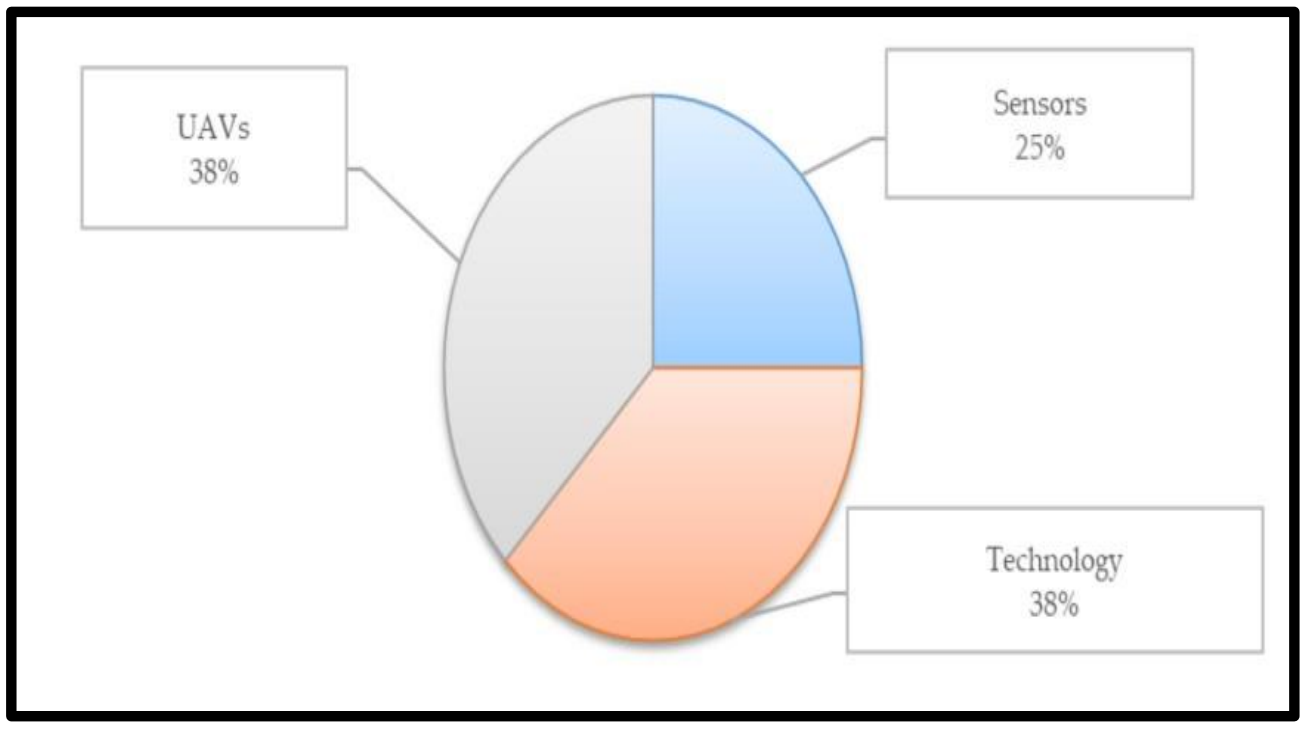

Similar sentiments were expressed by border security officials as depicted in Figure $\mathbf{5}$ below demonstrates who supports the use of satellites (40\%), UAV (30\%), sensors (20\%), and tower cameras $(10 \%)$ for border security.

\section{Figure 5: Opinions of SAPS officials on relevant space technology for border security}

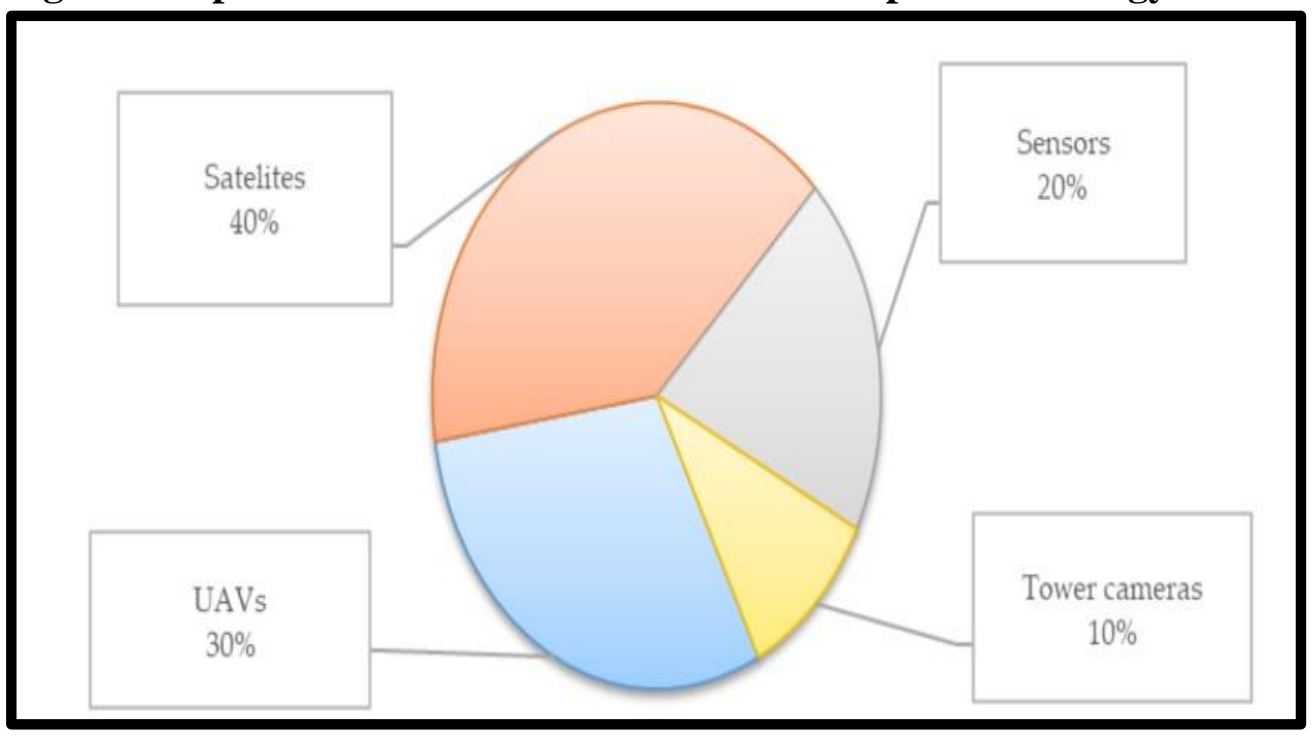

Border security experts as depicted in Figure 6 below also indicates a variety of space technologies that could be utilised for border security in South Africa. They mentioned that satellites, UAVs, and radars, each with a rate of $22 \%$. Other technologies mentioned by the experts were cameras and aerostats, with a relative frequency of $14 \%$ each, and sensors with a relative frequency of $7 \%$. 


\section{Figure 6: Opinions of border security experts on space technology for border security}

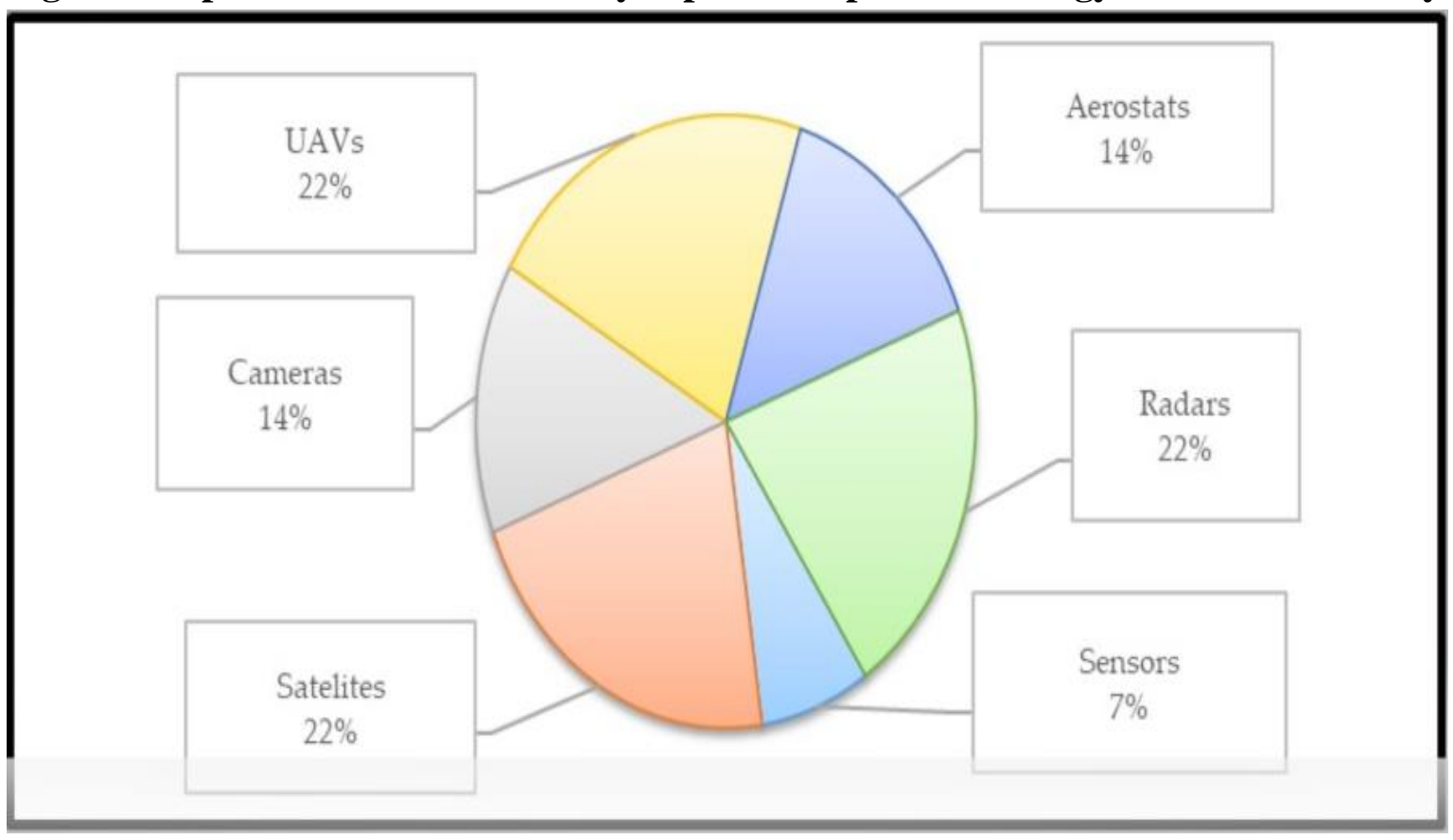

Further to the extent to which space technology could be employed to enhance border security in South Africa, border security experts provided several benefits that could be derived from employing space technology for border security in South Africa. As depicted in Figure 7 on the flowing page depicts border security experts' perceptions that space technologies could enhance border security in South Africa (33\%). One example provided by the participants was that space technology would enable border security entities in South Africa to cover a wider border area as opposed to the current conventional methods of border monitoring, such as observation posts, vehicle, and foot patrols.

Moreover, border security experts stated that space technology could be utilised for multiple functions $(33 \%)$ such as transporting supplies, monitoring the flow of traffic into designated border posts, and monitoring veld fires in remote border areas. The participants also said that space technology could offer proactiveness in the border security environment by being able to identify the risks before they reached the border and further alerting the authorities about the identified risks $(17 \%)$. 
International Journal of Innovation, Creativity and Change. www.ijicc.net

Volume 15, Issue 10, 2021

Figure 7: Opinions of border security experts on potential benefits of space technology

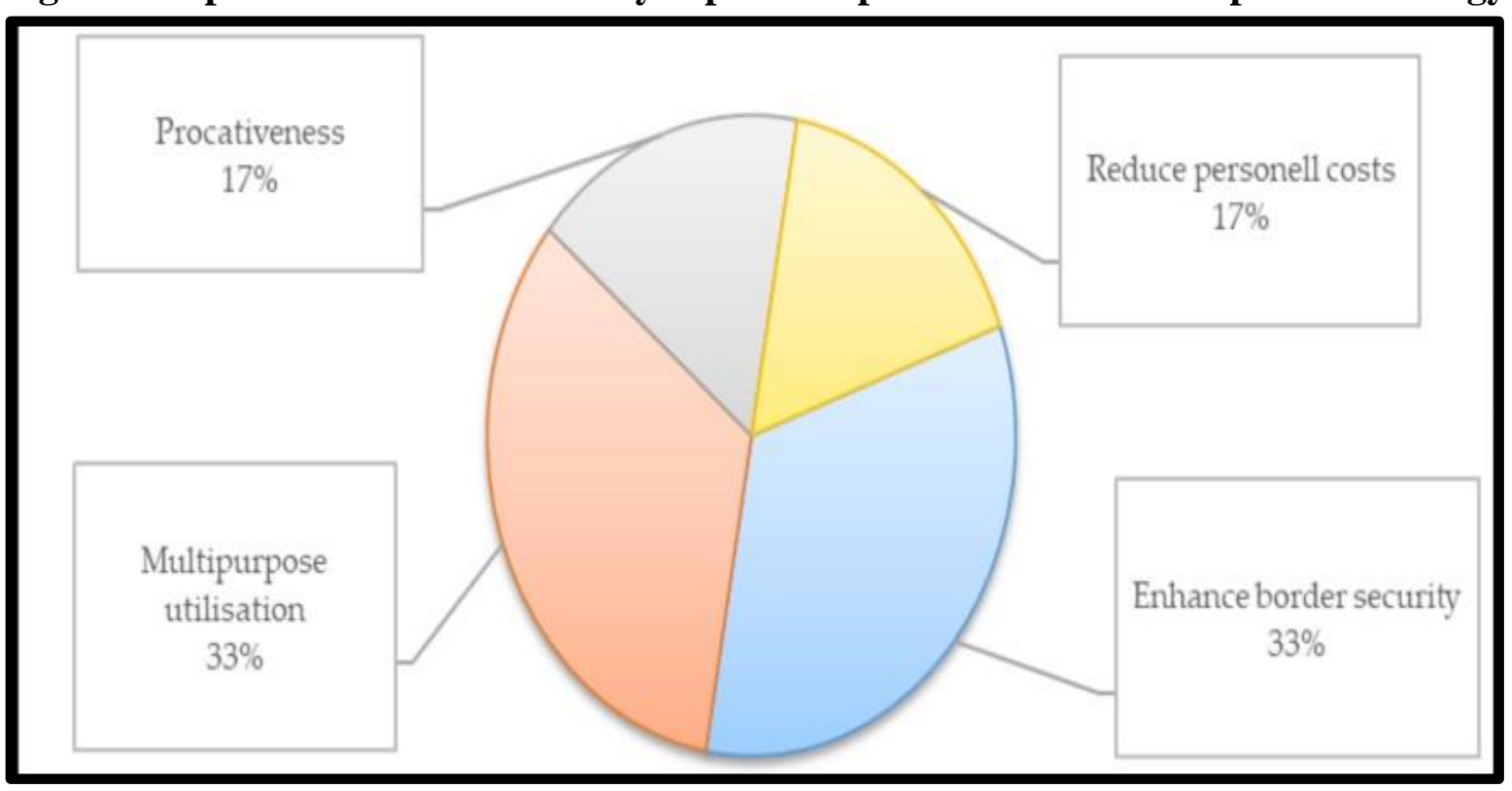

In line with Figure 8, UAV specialists were of a view that UAVs could be used in South Africa for ISR missions (40\%), border patrols (40\%), and multiple (20\%), such as transporting supplies to border agents on patrol in remote border areas.

Figure 8: Opinions of UAV specialists on adopting UAVs border security in South Africa

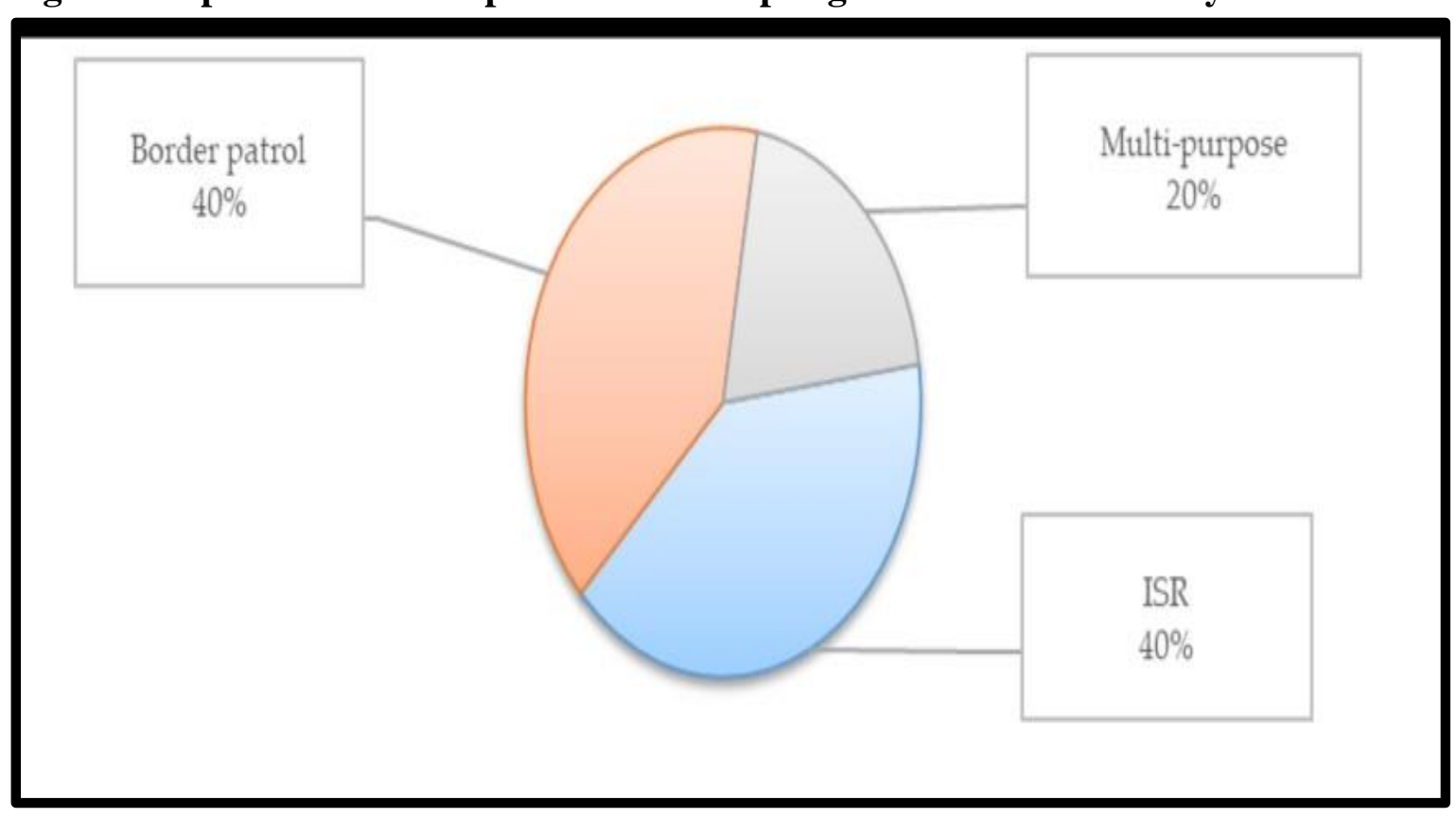

Moreover, as depicted in Figure 9 the satellite technology expert indicated that satellites could generally be used for defence (25\%), military (25\%), communication (25\%), and navigation $(25 \%)$ purposes. 
International Journal of Innovation, Creativity and Change. www.ijicc.net

Volume 15, Issue 10, 2021

Figure 9: Expert opinion on application of satellites border security

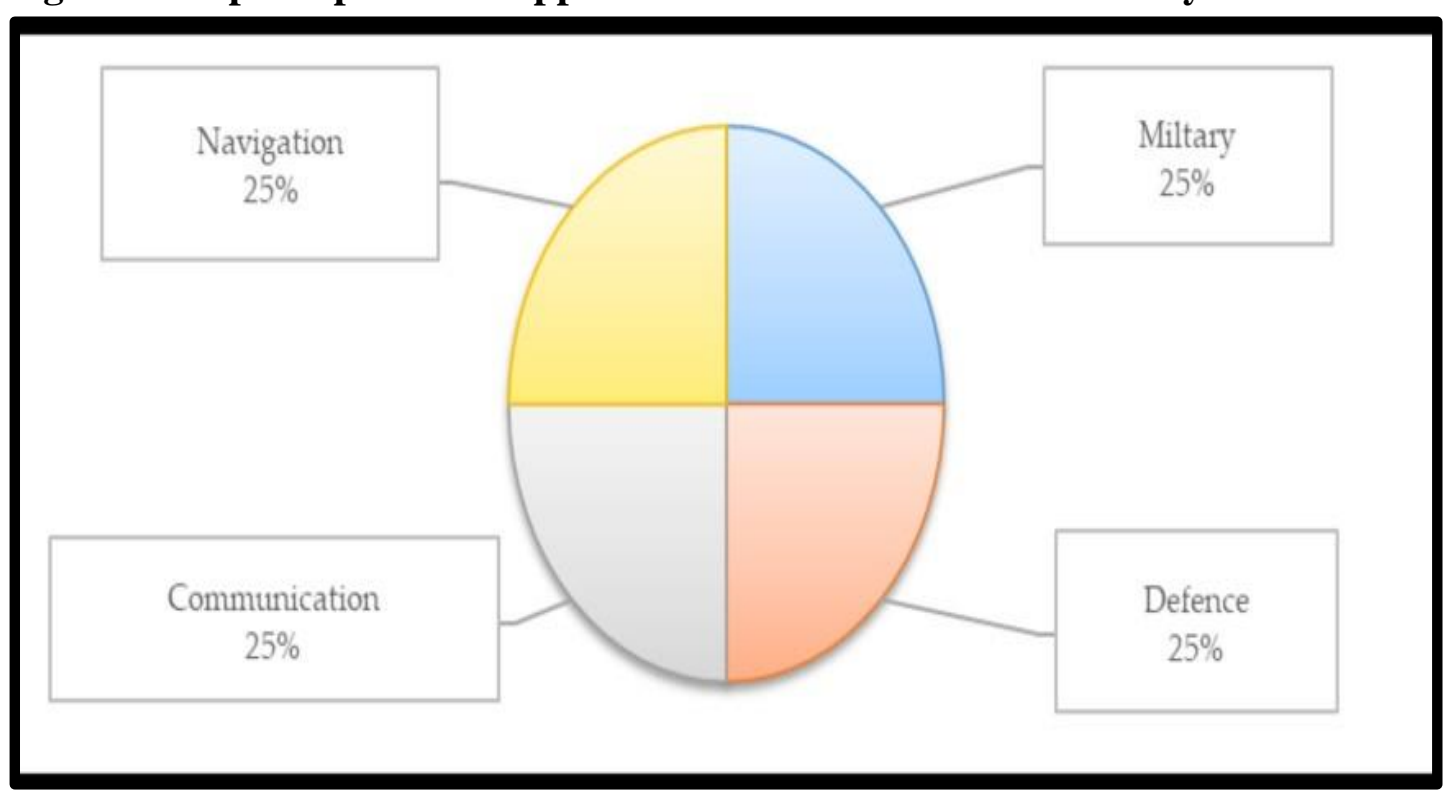

However, border security experts as highlighted in Figure 10 indicated that the deployment of technological solutions for border security management in South Africa will not be without constraints. In this instance, they mentioned several factors that could inhibit the application in border security in South Africa. They mentioned costs as the major potential inhibitor of employing space technology for border security in South Africa (31\%). The experts also mentioned legal requirements $(23 \%)$ and lack of skills and training on the use of space technology $(23 \%)$ as other potential inhibitors. Other potential inhibitors mentioned by the experts were the lack of appreciation of space technology as a solution to border security constraints (19\%) and the adoption of inappropriate technology (8\%).

Figure 10: Expert opinions on border security regarding space technology inhibitors

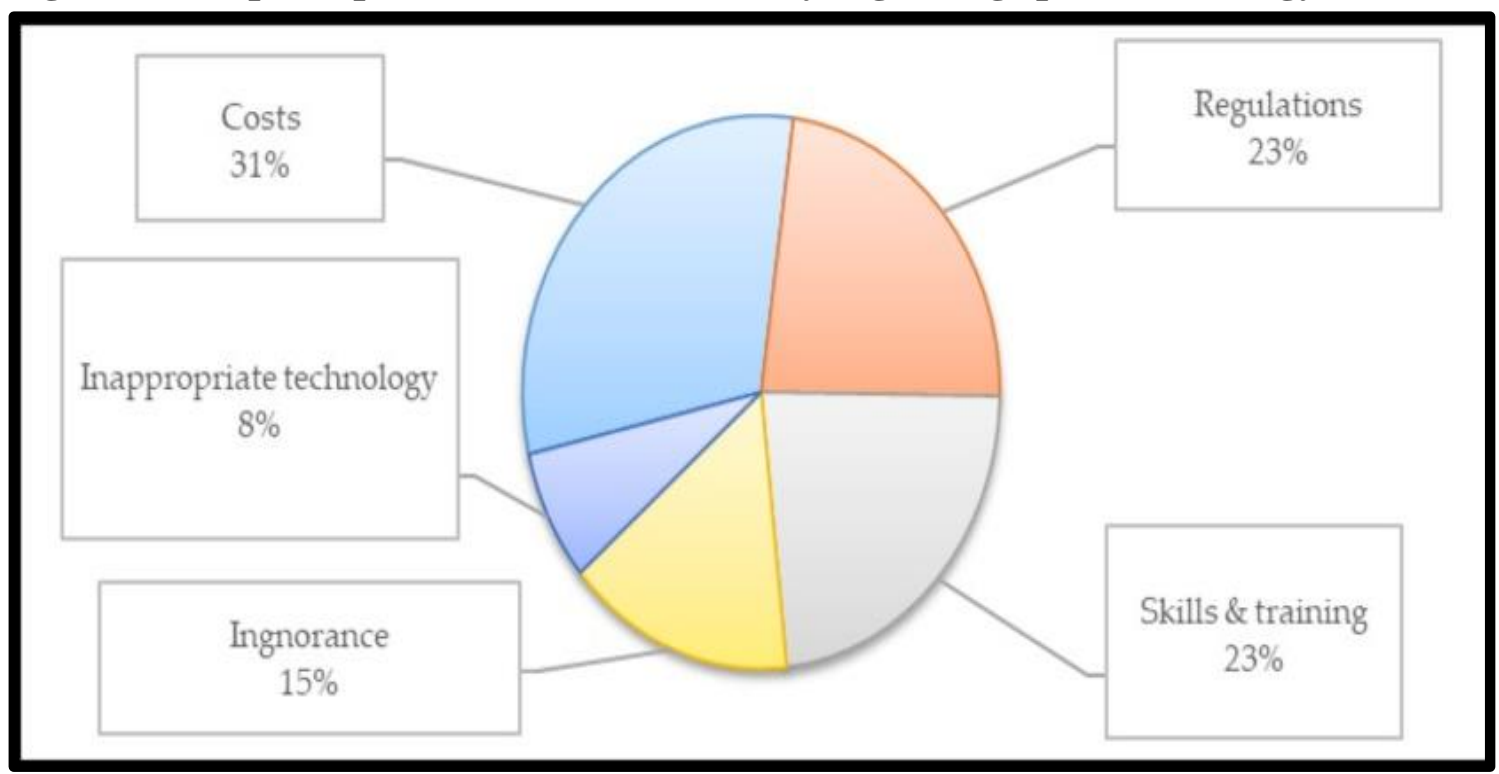


Moreover, the sole satellite expert interviewed in this study was not completely in favour of utilising satellites for border security. The participant said that deploying such as technology for border security in South Africa would not be easy. The participant as presented in Figure 11 mentioned a few but critical constraints that might be associated with the use of satellites for land border security such as huge costs (43\%). The participant further reiterated that satellite technology would not be effective for land border security (57\%), considering that it would be deployed to detect tiny objects such as humans and vehicles from a high altitude.

\section{Figure 11: Expert opinion on constraints of adopting satellite technology.}

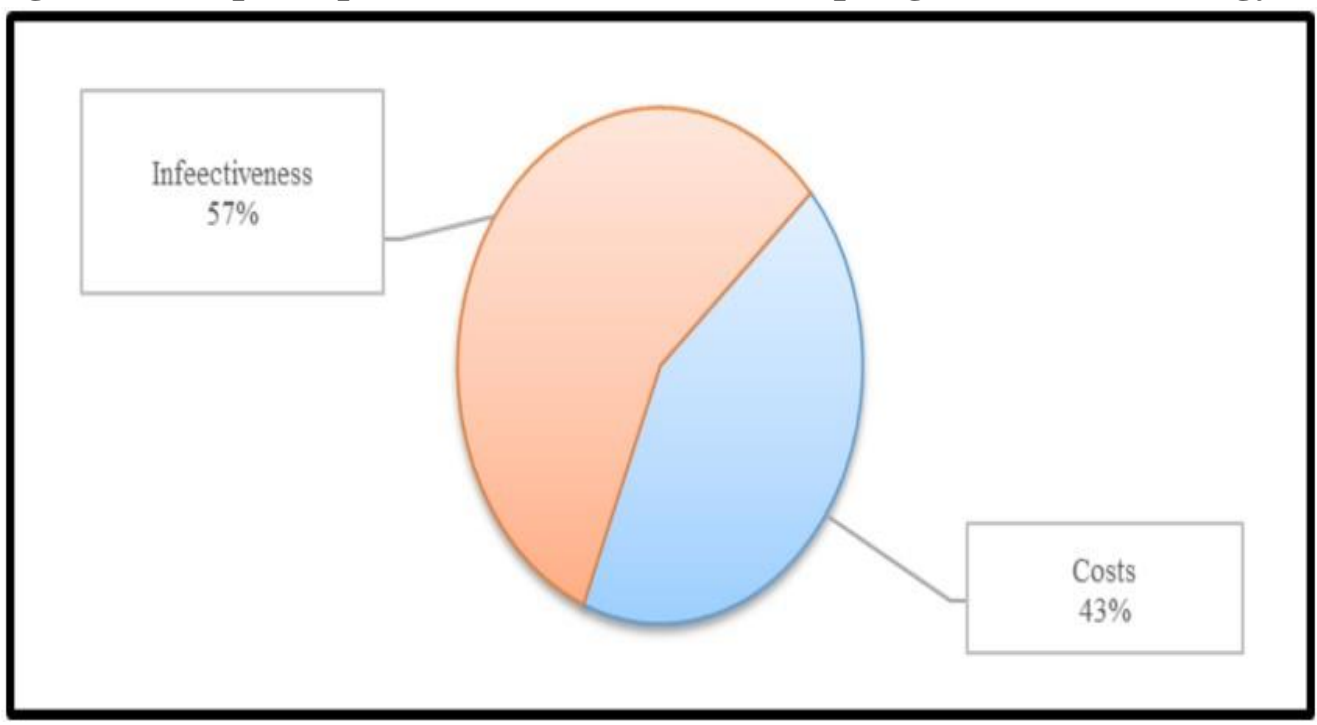

In this section of the study, all the participants provided their opinions on the extent to which space technology could be employed to enhance border security in South Africa. The participants also offered their opinions on the possible benefits of employing space technology. They further indicated that the deployment of space technology for border security would not be without constraints, which would have to be weighed against the potential benefits of using such a technology.

\section{Discussion}

The study found that the current border security measures in South Africa are ineffective and unable to curb an array of cross-border criminal activities. In assessing the constraints of border security in South Africa the study identified human resources constraints as a major challenge of border security in South Africa. It was deduced from the expressed views of the participants that border security authorities relied heavily on human resources to execute their border security mandate. The study further established that the current physical resources were inadequate to provide effective border security. It has also been revealed that the border environment in South Africa is characterised by harsh terrains and unfavourable road conditions, which makes it extremely difficult for border security authorities to patrol using 
conventional measures such as foot and vehicle patrols. The evidence in this study further indicated that the land border terrain in most parts of the border area in South Africa is long and open, densely populated and mountainous and bushy, which has proven to be too difficult for border authorities to monitor and control.

The function of border security comprises a combination of numerous socio-technical aspects related to this function. Technology has been identified as one of the most important sociotechnical aspects of border security. Many developed countries rely on hi-tech assets to control and monitor their international borders. They use many technological solutions to prevent cross-border criminal activities, such as illegal migration and the smuggling of drugs and narcotics. The objective of employing technology in any security system is mainly to implement fundamental security solutions, which could enhance the level of security to the desired levels in any given security context. Similarly, the utilisation of technology in the border security environment seeks to augment existing border security measures and ultimately enhance the level of border security. This study revealed that UAVs and satellites should be used for border security in the South Africa. The study established that the use of these technologies, together with other technological solutions such as radars and sensors, could achieve better border security results.

Even though this study supported the use of UAVs and satellites for border security, UAVs received more recognition than satellites due to several factors, including cost and effectiveness. The study further established the advantages of UAVs; namely, that they were cheaper than satellites and they could be controlled by a single operator, thus, reducing personnel-associated costs. UAVs were also identified as fast technological solutions, which could patrol large border areas. They also had a wider area of visibility than conventional surveillance methods, such as human eyes, which increased the probability of detecting illegal cross-border movements. UAV are also capable of executing intelligence, surveillance, and reconnaissance missions. They could also be used for other purposes, such as the delivery of supplies to border guards in remote areas. Moreover, their ability to feed real-time images and to follow a target being pursued in harsh and thinly populated terrains provided them with an advantage over vehicles and foot patrols. The harsh and dangerous terrain in most parts of the South African borders exposed border guards to several dangers. Accordingly, the use of UAVs in the border security environment could limit the exposure of border security officials to occupational hazards associated with foot patrols, such as encounters with wild animals, operating under extreme weather conditions, walking, or driving in unfavourable terrains that might cause injuries to border guards on patrol, or conducting physical patrols and surveillance activities at night in dangerous situations. When live images and videos were fed to the local command centre through UAVs, the command centre could dispatch adequately equipped response personnel, based on the threat and risk identified by the UAV.

Despite all these benefits, this study also revealed that the utilisation of UAVs for border security in South Africa would not be as easy as anticipated. The study pointed out some of the 
factors to be considered by border security authorities. The factors included the regulatory framework, which was widely regarded as a potential obstacle. Other issues for consideration revealed in this study on the utilisation of UAVs were the cost implications associated with the procurement, operation, and maintenance of UAVs. The study also pointed out that the operators of UAVs would need to be trained, which would escalate the costs of utilising drones. Thus, the decision to utilise UAVs for border security in South Africa should be based on a comprehensive cost-to-benefit analysis. Ignoring the value that UAVs could add to border security and preferring to stick to old and ineffective methods of border surveillance were also identified as other critical factors that could hamper the full utilisation of UAVs for border security in South Africa.

Satellites were also identified by this study as potential solutions to the problem of border security in South Africa. They could add value in border security through the provision of earth observation, remote sensing, and navigation and communication capabilities. This study further found that satellites could provide border security authorities with detailed images of high-risk areas with an increase in illegal border crossings. They could also conduct wide area surveillance, as well as access remote border areas. Satellites could further be used in a variety of activities, including monitoring targeted border areas, disaster management, as well as search and rescue missions. Images obtained from satellites could help border security authorities to detect illegal trafficking paths along a country's international borders. Moreover, this study pointed out that regular traffic across a border area interfered with vegetation and soils and was likely to leave visible tracks that could be detected remotely by orbital sensors. The ability to gather intelligence was a critical component of a border security system. This allowed border security authorities to have a good knowledge of their area of operation and further enabled them to be proactive in their border security operations, as pointed out by this study.

Notwithstanding the various benefits offered by satellites, in assessing the potential drawbacks of utilising satellites for border security, this study established that South Africa might not be in the financial position to utilise satellites for border security. It was revealed in this study that the country would require dozens of satellites fitted with high-resolution cameras to monitor the borders, which would result in huge financial expenses. However, it was also established that the costs of developing and launching satellites had dropped significantly in recent years, especially with small satellites like CubeSats and nanosats. Considering South Africa's capability of developing and launching satellites, including microsats such as Sumbandila, nSight 1 and ZA-Aerosat, these capabilities could be exploited to develop affordable satellites that could be used for border security (Parliamentary Monitoring Group, 2017; Wood \& Weigel, 2012; South Africa, 2020). Another drawback associated with the use of satellites was their effectiveness to detect small items, such as people crossing a border. It could also be difficult to discern between people and animals, if using a satellite. It was pointed out that these drawbacks could be addressed by developing more expensive satellites, which were fitted with sophisticated high-resolution cameras. Considering the costs implication of developing, 
launching and utilising satellites for border security in South Africa, it might not be beneficial to utilise such technologies for live border monitoring. Satellites could, however, be utilised to detect illegal trafficking paths along the country's international borders by identifying and assessing regular traffic across the border, which usually interfered with vegetation and soils, and were likely to leave visible tracks that could be detected remotely by satellite technologies. Evidence from this study pointed out that both satellites and UAVs could be integrated with other socio-technical aspects of border security. The evidence further indicated that other technologies, identified in this study, such as ground sensors, radars, and cameras, all linked to a central command centre could be integrated with these space technologies for the provision of better and effective solutions to South Africa's border security constraints. The human element of the socio-technical aspects of border security would remain relevant in this setting. Border security guards would still be required to respond to border security incidents and to operate those technologies.

\section{Conclusion}

The establishment of the BMA provides an opportunity to review the current ineffective human-driven approaches to border security and overcome current barriers of adopting technology. It can be argued that the success of the BMA or border security authorities in South Africa will largely be dependent on the utilisation of effective border security technology, as identified in this study. There is a dire need to employ effective border security technologies and solutions consisting of satellites, UAVs, and other hi-tech assets, as identified in this study, to enhance border security in South Africa. It has also been established in this study that the proposed technologies could be used for multiple purposes and across a multitude of actors in government and the private sector. Thus, the adoption of space technologies would result in other added benefits, apart from their primary use in border security.

\section{Recommendation}

The border security function in South Africa should be technology driven. Technology should be a central feature of the South Africa border security management strategy. The monitoring and control of South Africa's vast land borders require the adoption and optimal utilisation of technological innovations and solutions such as satellites, UAVS, radars, cameras, and sensors. The effective integration of various technological solutions and other border security assets should be an important feature of border security in South Africa. This will ensure the optimal utilisation of all available border security resources through the interoperability of systems. Moreover, technology evolves. Similarly, threats and risks to borders security also evolve and transitional criminal elements will always alter their methods of operating to avoid detection and interception. Therefore, the continuous revitalisation of technological solutions in line with global technological trends becomes necessary. Technology should be able to adapt to the everchanging threats and risk to border security and should always be able to meet the required needs of border security authorities. There is also a need for a new style of leadership in the 
border security environment and a shift in organisational culture to that will embrace technology and innovation as a critical success factor of border security management in South Africa. Border security officials should be able to utilise all the technological resources at their disposal. They should be equipped with the necessary skills to operate acquired technologies. Therefore, the introduction of technology should be accompanied by the corresponding training of border security officials. Border security authorities should also prioritise the capacity building of border guards in line with technological developments and the introduction of technological solutions in the border security management environment. 
International Journal of Innovation, Creativity and Change. www.ijicc.net

Volume 15, Issue 10, 2021

\section{REFERENCES}

Akinyemi, O. 2013. Globalization and Nigeria border security: issues and challenges, International Affairs and Global Strategy, 11(1): 1-8.

Alkhathami, M., Alawazzi, L. \& Elkateeb, A. 2015. Border surveillance and intrusion detection using wireless sensors network, International Journal of Advance in Engineering and Technology, 8(2): 17-29.

Andreas, P. (2003). Redrawing the line: borders and security in the twenty-first century, International Security, 28(2), 78-111. Available online from: http://www.jstor.org/stable/4137469 (accessed 21 January 2020).

Baker, D. 2009. A border patrol for South Africa? Available from: https://issafrica.org/amp/isstoday/a-border-patrol-for-south-africa (accessed 3 July 2019).

Braun, V. \& Clarke, V. 2006. Using thematic analysis in psychology. Qualitative research in Psychology, 3 (2): 77-101.

Caparini, $\mathrm{M}$ and Marenin,O eds. 2006. Borders and Security Governance. Managing Borders in a Globalised World, Vienna: LIT Verlag.

Corti, L \& Gregory, A. 2011. AQDAS comparability: what about CAQDAS data exchange?, Forum of Social Qualitative Research, Volume 12, No. 1, Art. 35 - January 2011.

Coulter, L.L., Lippitt, C.D., Stow, D.A., \& McCreight, R.W. 2011. Near real-time change detection for border monitoring. ASPRS 2011 Annual Conference Milwaukee, Wisconsin May 1-5, 2011. Online. Available from: http://www.asprs.org/a/publications/proceedings/Milwaukee2011/files/Coulter.pdf (accessed 13 May 2020).

Cowen, Tyler. 2002. Creative Destruction: How globalization is changing the worlds cultures. Princeton: Princeton University Press.

Crush, J \& Williams, V. 1999. Southern African Migration Project. Criminal Tendencies: Immigrants and Illegality in South Africa Migration Policy Brief No. 10 Series Editors. Online. Available from: http://samponline.org/wpcontent/uploads/2016/10/brief10.pdf (accessed 12 March 2020).

De Vos, A.S., Strydom, H., Fouché, C.B. and Delport, C.S.L. 2005. Research at Grass Roots For the Social Science Professionals. 3rd Edition, Van Schaik, Pretoria.

DefenceWeb. 2020. Border safeguarding is a Department of Defence priority. Available online from:https://www.defenceweb.co.za/featured/border-safeguarding-is-a-department-ofdefence-priority/ (accessed 7 June 2020).

DeNardo, A.M. \& Levers, L.L. 2002. Using NVivo to analyze qualitative data. Education. Available online fromhttp://www.education.duq.edu/institutes/PDF/papers2002/DeNardo\&Levers.pdf [accessed, 25 March 2020].

Emad, F. 2013.Advanced Border Intrusion Detection and Surveillance Using Wireless Sensor Network Technology, International Journal of Communications, Network and System Sciences 6(5):251-259. Available online from: DOI: 10.4236/ijens.2013.65028. 
International Journal of Innovation, Creativity and Change. www.ijicc.net

Volume 15, Issue 10, 2021

Erasmus, G. 2020. New Border Management for South Africa amidst unresolved systemic Issues. Tralac. Available online from: https://www.tralac.org/news/article/14393 (accessed 9 June 2020.

Esterhuyse, A.J. 2019. South African border protection: a historical and theoretical Perspective. University of Stellenbosch. Online. Available from: http://www.sun.ac.za/english/faculty/milscience/sigla/Documents/Borders\%202019/S outh\%20African\%20Border\%20Protection.pdf (accessed 2 May 2020).

Felemban, E. 2013. Advanced border intrusion detection and surveillance using wireless sensor network technology, International Journal of Communications, Network and System Sciences 6(5):251-259. Available online from: DOI: 10.4236/ijcns.2013.65028 (accessed 1 May 2020).

Gadda, J.S., \& Patil, R.D. 2013. Quadcopter (UAVS) for border security with GUI system, International Journal of Research in Engineering and Technology, 2(12):620-624.

Given, L.M. 2008. The SAGE encyclopaedia of qualitative research methods. Thousand Oaks: SAGE.

Klauser, F. \& Pedrezo, S. 2017. Big data from the sky: popular perceptions of private drones in Switzerland, Geographic Helvecticia, 72(1): 231-239.

Kumar, K. 1989. Conducting key informant interviews in developing countries. A.I.D. Program Design and Evaluation Methodology Report No. 13. http://www.slideshare.net/achintbt/usaid-tips-series (accessed 4 August 2020)

Kumar, R. 2019. Research methodology: A step-by-step guide for beginners. 5th. ed. Thousand Oaks, CA, Sage, 2019.

Lynch, J. K. and Hadjimatheou, K. 2017. Challenges and expectations of safeguarding and anti- trafficking initiatives at the UK Border. Available online from: https://www.law.ox.ac.uk/researchsubjectgroups/centrecriminology/centrebordercrimi nologies/blog/2017/07/challenges-and (accessed 30 May 2020).

Mahlangu, S.B. \& Obioha, E.E. 2015. Challenges in land border security and control experienced by the South African police service and other agencies, Acta Criminologica: Southern African Journal of Criminology Special Edition No 4/2015: Criminology in democratic South Africa: Coming of age: 107-132.

Maqhina, M. 2019. 2019. Motsoaledi wants border bill to be fast-tracked. Independent Online. Available from: https://www.iol.co.za/news/politics/motsoaledi-wants-border-bill-tobe-fast-tracked-29026645 [accessed 18 September 2019].

Molemma, N. 2017. The role of the military in combating human trafficking: A South African perspective, South African Journal of Military Studies, 45(2): DOI: https://doi.org/10.5787/45-2-1211 (accessed 2 February 2020).

Okumu, W. 2016. Border management and security in Africa. ResearchGate, available online from:

https://www.researchgate.net/publication/308983535_Border_Management_and_Secu rity_inAfrica (accessed 1 October 2019). 
International Journal of Innovation, Creativity and Change. www.ijicc.net

Volume 15, Issue 10, 2021

Parliamentary Monitoring Group. 2017. Space: Department of Science and Technology briefing. Science and Technology. Available online from:

https://pmg.org.za/committee-meeting/24446/ (accessed 12 September 2019).

Pedrozo, S. 2017. Swiss military drones and the border space: a critical study of the surveillance exercise by border guards, Geographica Helvetica, 72(1): 97-107. Available from: https://www.geogr-helv.net/72/97/2017/ [accessed 10 May 2019].

SA News. 2019.Protecting SA's borders at all costs. Available from: https://www.defenceweb.co.za/security/border-security/protecting-sas-borders-atallcosts/ [accessed 15 May 2019].

Segell, G. 2005. Three intelligence methodologies for border defence and border security, Scientia Militaria, South African Journal of Military Studies, Vol 33 (2): 1-22. Available from: https://www.ajol.info/index.php/smsajms/article/view/81052 [accessed 10 May 2019].

Shishkov, B., Hristozov, S., Janssen, M., \& van Den Hove, J. 2017. Drones in Land Border Missions: Benefits and Accountability Concerns, ICTRS'17: Proceedings of the 6th International Conference on Telecommunications and Remote Sensing, November 2017 Pages 77-86. Available online from: https://doi.org/10.1145/3152808.3152820 (accessed 2 June 2020).

Solomon, H. 2015. African solutions to Africa's problems? African approaches to peace, security and stability, Scientia Militaria, South African Journal of Military Studies, 43(1): 45-76.

South Africa. 2020. South African Government, Justice, Crime Prevention \& Security Cluster. Available online from: https://www.gov.za/about-government/justice-crimeprevention-security-cluster-1 (accessed 2 May 2020).

Szechtman, R., Kress, M., Lin, K., \& Cfir, D. 2007. Models of sensor operations for border surveillance, Naval Research Logistics (NRL) 55 (1): 27-41, 2008.

Tati, G. 2008. The immigration issues in the post-apartheid South Africa: Discourses, Policies and Social Repercussions, Espace populations sociétés, 2008/3 | 2008, 423-440.

The Economic Times. 2019. Satellites to help border forces. Available online from: https://economictimes.indiatimes.com/topic/satellites-to-help-border-forces/4 (accessed 2 June 2020).

Wang, P., Sun, Z., Vuran, M. C., Al-Rodhaan, M. A., Al-Dhelaan, A. M., \& Akyildiz, I. F. 2011. Topology analysis of wireless sensor networks for sandstorm monitoring. In Proceedings of IEEE ICC 2011. Available online from: https://doi.org/10.1109/icc.2011.5963393 (accessed 1 March 2020).

Welman, J., Kruger, S.J., \& Mitchel, B. 2005. Research methodology. 3rd Edn. Cape Town: Wilosn, J.R. 2018. The role of technology in securing the nation's borders. Military and Aerospace Electronics, available online from: https://www.militaryaerospace.com/unmanned/article/16707261/the-role-oftechnology-in-securing-the-nations-borders (accessed 23 December 2019). 
International Journal of Innovation, Creativity and Change. www.ijicc.net

Volume 15, Issue 10, 2021

Wood, D \& Weigel, A. 2012. Charting the evolution of satellite programs in developing countries, The Space Technology Ladder, Space Policy, xxx : 1-10.

\section{Documentary sources}

Council for Scientific and Industrial Research. 2017. SANDF launches new range of military vehicles to improve its border safeguarding capability, Publication Date: Thursday, November 30, 2017. Available online from: https://www.csir.co.za/sandf-launchesnew-range-military-vehicles-improve-its-border-safeguarding-capability (accessed 5 June 2020).

DefenceWeb. 2009. Police never mastered border security: analysts, written by Leon Engelbrecht, 20th Nov 2009. Available online from: https://www.defenceweb.co.za/security/civil-security/police- never-masteredborder-security-analysts/ (accessed 3 June 2020).

DefenceWeb. 2018. SANDF Way Ahead: Priorities and Challenges Posted on June 19, 2018 | by Robbin Laird . Available online from: https://sldinfo.com/2018/06/sandf-wayahead-priorities-and-challenges/ (accessed 2 June 2020).

DefenceWeb. Border safeguarding is a Department of Defence priority. Available online from:https://www.defenceweb.co.za/featured/border-safeguarding-is-a-department-ofdefence priority/ (accessed 7 June 2020).

Eyewitness News. 2017. The SANDF is dominating South Africa's borders. Available online from:

https://www.google.co.za/url?sa=t\&rct=j\&q=\&esrc=s\&source=video\&cd=\&cad=rja $\underline{\text { \&uact }=8 \& \text { ved }=2 \text { ahUKEwjyvsDP3cjuAhVxoFwKHSH5Ds0QtwIwBnoECAEQAg\&u }}$ $\mathrm{rl}=\mathrm{https} \% 3 \mathrm{~A} \% 2 \mathrm{~F} \% 2 \mathrm{Fwww}$. youtube.com\%2Fwatch\%3Fv\%3D3Ag21MvEg8\&usg=A OvVaw2QXac5F_KRu318LHyszLKA (accessed 12 June 2020).

Eyewitness News. 2018. Life on the line: SA's military fights crime on the border. Available online from:

https://www.google.co.za/url?sa=t\&rct=j\&q=\&esrc=s\&source=video\&cd=\&cad=rja $\underline{\text { \&uact }=8 \& v e d=2 \mathrm{ahUKEwjyvsDP3} \text { cjuAhVxoFwKHSH5Ds0QtwIwB3oECAQQAg\& }}$ url=https \%3A\%2F\%2Fwww.youtube.com\%2Fwatch\%3Fv\%3DR5AGLipe7FQ\&usg =AOvVaw22LvGS9C-moRdAxaMWubDt (accessed 11 June 2020).

Eyewitness News. 2019. 'Borders' Episode 1: Guns, Drugs \& People. Available online from: https://www.google.co.za/url?sa=t\&rct=j\&q=\&esrc=s\&source=video\&cd=\&cad=rja \&uact=8\&ved=2ahUKEwiP4rCY38juAhVGQUEAHSP0A0c4ChC3AjACegQIABA C\&url=https \%3A\%2F\%2Fewn.co.za\%2Ffeatures\%2Fborders-episode1gunsdrugsandpeople\&usg=AOvVaw23rn8rCewJoTUNYILSyjI0 (accessed 12 June 2020).

Gibson, K. 2014. SANDF needs more budget to meet commitments. African Defence Review, Defence Industry News. Available online from: https://www.africandefence.net/sandfneeds-more-budget-to-meet-commitments/ (accessed 4 June 2020). 
International Journal of Innovation, Creativity and Change. www.ijicc.net Volume 15, Issue 10, 2021

Independent Online. 2017. SANDF in border crime drive. By Virgilatte Gwangwa Nov 17, 2017. Available online from: https://www.iol.co.za/pretoria-news/news/sandf-inborder-crime-drive-12046670 (accessed 3 June 2020).

Independent Online. 2018. R50bn needed by SANDF to protect borders, By SAKHILE NDLAZI Oct 19, 2018. Available online from: https://www.iol.co.za/pretorianews/r50bn-needed-by-sandf-to-protect-borders-17550387 (accessed 6 June 2020).

Kruger National Park. SANDF to resume patrol of South Africa's borders. Available online from: http://www.krugerpark.co.za/krugerpark-times-e-5-sandf-to-resume-patrol25208.html (accessed 7 June 2020).

News24. No money to modernise current SANDF equipment. Available online from: https://www.google.co.za/url?sa=t\&rct=j\&q=\&esrc=s\&source=video\&cd=\&cad=rja \&uact=8\&ved=2ahUKEwjov9D738juAhVilFwKHbryBU4QtwIwBHoECAIQAg\&url $=$ https $\% 3 \mathrm{~A} \% 2 \mathrm{~F} \% 2 \mathrm{Fwww}$. news $24 . \mathrm{com} \% 2 \mathrm{Fnews} 24 \% 2 \mathrm{Fsouthafrica} \% 2 \mathrm{Fnews} \% 2 \mathrm{Fno}-$ money-to-modernise-current-sandf-equipment-parliament-hears-

20200902\&usg=AOvVaw3oiJ-7iADQ510GQveqjOXW (accessed 15 June 2020).

Newzroom Afrika. 2020. SANDF arrests around 46 people crossing the border fence. Available online

https://www.google.co.za/url?sa=t\&rct=j\&q=\&esrc=s\&source=video\&cd=\&ved=2ah

UKEwjyvsDP3cjuAhVxoFwKHSH5Ds0QtwIwCXoECAIQAg\&url=https\%3A\%2F

\%2Fwww.youtube.com\%2Fwatch\%3Fv\%3D1skQuVsTKj4\&usg=AOvVaw12TPnvB OHjit0VO11FqEvK (accessed 10 June 2020).

Parliamentary Monitoring Group. Defence and Military Veterans. Border Control: briefing by Chief of Joint Operations, South African National Defence Force (SANDF), 16 February 2010, Chairperson: $\mathrm{Mr} \mathrm{M}$ Booi (ANC). Available online from: https://pmg.org.za/committee-meeting/11206/ (accessed 1 July 2020).

SA Defence News. SANDF Mobility packs Roll Out. Available online from: https://www.google.co.za/url?sa=t\&rct=j\&q=\&esrc=s\&source=video\&cd=\&cad=rja $\underline{\text { \&uact }=8 \& \text { ved=2ahUKEwjyvsDP3cjuAhVxoFwKHSH5Ds0QtwIwBXoECAcQAg\&u }}$ rl=https\%3A\%2F\%2Fwww.youtube.com\%2Fwatch\%3Fv\%3DaE9MMPXLL1w\&usg =AOvVaw1m0KUwQiVhkQ2r-cy4CApc (accessed 13 June 2020).

SABC News. 2018. SANDF strengthens cross-border security. Available online from: https://www.google.co.za/url?sa=t\&rct=j\&q=\&esrc=s\&source=video\&cd=\&cad=rja

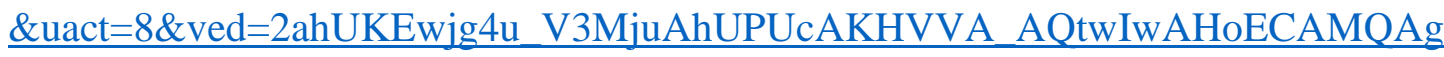
\&url=https $\% 3 \mathrm{~A} \% 2 \mathrm{~F} \% 2 \mathrm{Fwww} . y$ outube.com\%2Fwatch\%3Fv\%3DuSBfoxMXKUg\&u sg=AOvVaw1XgFS56KCs2liyPhashyR_ (accessed 13 June 2020).

SABC News. 2020. Drones to be deployed at Beitbridge border to help fight illegal entry into SA. Available online from: https://www.google.co.za/url?sa=t\&rct=j\&q=\&esrc=s\&source=video\&cd=\&cad=rja $\underline{\text { \&uact }=8 \& v e d=2 \mathrm{ahUKEwi86OK} 34 \mathrm{MjuAhXjQUEAHVVaDxM} 4 F B C 3 A j A E e g Q I C B}$ AC\&url=https $\% 3 \mathrm{~A} \% 2 \mathrm{~F} \% 2 \mathrm{Fwww}$. sabcnews.com\%2Fsabcnews\%2Fdrones-to-be- 
deployed-at-beit-bridge-border-to-help-fight-illegal-entry-intosa\%2F\&usg=AOvVaw2JV5uTb8A6em-s6V3wg9vr (accessed 5 June 2020).

SABC. 2018. SANDF deployed on SA-Mozambique border. Available online from: https://www.google.co.za/url?sa=t\&rct=j\&q=\&esrc=s\&source=video\&cd=\&cad=rja \&uact=8\&ved=2ahUKEwjT6_CP3cjuAhXDh1wKHZCjD4YQtwIwAnoECAkQAg\& url=https\%3A\%2F\%2Fwww.youtube.com\%2Fwatch\%3Fv\%3DpGq133misow\&usg= AOvVaw11jUqSaQgTSnMMSsfGZ9_1 (accessed 7 June 2020).

South African Broadcasting Corporation. 2018. SANDF claims progress in dealing with cross border crimes. Available online from: https://www.sabcnews.com/sabcnews/sandfsays-cross-border-crimes-have-decreased/ (accessed 7 June 2020).

The Citizen. SANDF needs more than R50bn to keep country safe. Available online from: https://citizen.co.za/news/south-africa/2025006/sandf-needs-more-than-r50bn-tokeep-country-safe/ (accessed 7 June 2020).

The Conversation. South Africa's army is in steady decline and nothing's being done to fix it, April 5, 2017. Available online from: https://theconversation.com/south-africas-armyis-in-steady-decline-and-nothings-being-done-to-fix-it-74712 (accessed 6 June 2020). 